Communication

\title{
One-Pot Tandem Synthesis of Nitriles and Amides from Biomass Platform Compounds
}

Xiu-Zhi Wei ${ }^{1,2}$, Jianguo Liu ${ }^{3,}{ }^{*}$, Longlong Ma ${ }^{1,3, *}$

1. Department of Engineering Science, University of Science and Technology of China, Hefei 230026, P.R. China; E-Mails: wxz123@mail.ustc.edu.cn; mall@seu.edu.cn

2. CAS Key Laboratory of Renewable Energy, Guangdong Provincial Key Laboratory of New and Renewable Energy Research and Development, Guangzhou Institute of Energy Conversion, Chinese Academy of Sciences, Guangzhou 510640, P. R. China

3. Key Laboratory of Energy Thermal Conversion and Control of Ministry of Education, School of Energy and Environment, Southeast University, Nanjing 210096, P. R. China; E-Mail: liujg@seu.edu.cn

* Correspondences: Jianguo Liu and Longlong Ma; E-Mails: liujg@seu.edu.cn; mall@seu.edu.cn

Academic Editor: Robert Wojcieszak

Special Issue: Recent Advances in Catalysis for Biomass Conversion

Catalysis Research

2022, volume 2 , issue 1

doi:10.21926/cr.2201004
Received: December 28, 2021

Accepted: February 13, 2022

Published: February 21, 2022

\begin{abstract}
In recent years, research on converting biomass platform compounds into high-value chemicals and pharmaceutical intermediates has garnered huge interest. Nitrile and amide groups are key structures in natural products and biologically active molecules. The direct conversion of biomass platform compounds into nitriles and amides will undoubtedly be an important guide for biomass utilization. In this paper, a facile and efficient triphosgeneassisted one-pot conversion for aldehydes and ketones into nitrile and amides is presented. Triphosgene is a phosgene alternative that contains both ester linkage and chloromethyl units and easily reacts with oximes for the preparation of nitriles and amides. However, due to the hydrolysis of oximes to aldehydes or ketones, the reaction of oximes with triphosgene cannot fully convert the corresponding nitriles and amides. The protocol tandem ensures a smooth
\end{abstract}

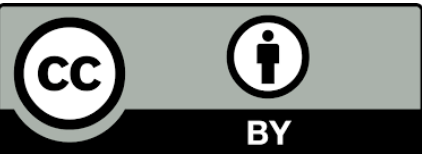

(C) 2022 by the author. This is an open access article distributed under the conditions of the Creative Commons by Attribution License, which permits unrestricted use, distribution, and reproduction in any medium or format, provided the original work is correctly cited. 
process without the use of organic bases or metal catalysts. Using biomass-derived platform compounds, various functionalized aromatic, aliphatic, and allylic aldehydes and ketones were successfully converted to nitriles and amides in excellent yields. In comparison to step-by-step reactions, this tandem strategy features multi-step reactions in one pot, mild reaction conditions, and fewer by-products.

\section{Keywords}

Tandem synthesis; triphosgene; nitriles and amides; biomass platform compounds

\section{Introduction}

Nitrile and amide groups are key structures of natural products, biologically active molecules, agrochemicals, dyes, or materials science. In the past decade, nitriles have been produced from the conversion of oximes via dehydration [1] and substitution reactions involving cyanogen reagents [26]. Furthermore, for the synthesis of amides, carboxylic acid derivatives and amines are traditionally applied via a condensation reaction in harsh conditions [7]. The majority of the synthesis was performed with toxic reagents and cumbersome experimental operations. There has been considerable progress in the generation of nitriles from aldehydes, which has been successfully applied to the wide substrate scope of aldehydes. However, there are few suitable methodologies for the synthesis of both nitriles and amides from aldehydes and ketones, respectively. In comparison to the traditional nucleophilic substitutions using HCN or metal cyanides [8-11], as well as the recent oximation-dehydration strategy [12] with the prepared reagents [13] or additional alkali $[14,15]$, an environment-friendly alternative was designed using triphosgene. This reagent is inexpensive and can be used without further preparation.

In a recent report [16], the reaction site of oxime was used in the chemical detection of phosgene. Many researchers have reported the synthesis of nitriles or amides from various oximes with phosgene or its substitutes, such as triphosgene and diphosgene. However, most of these applications suffer from toxic phosgene overflow under alkaline conditions (such as adding TEA to the reaction system) and have narrow substrate scope. Phosgene and its substitutes are important industrial feedstocks used in the production of polyurethanes, polycarbonates, pharmaceuticals [17], insecticides, and aniline dyes [18, 19]. Also, phosgene and diphosgene are highly toxic lung irritants even at low conversions. Due to the hazardous effects, they were utilized as chemical warfare agents (CWAs) during World War I and World War II [20]. Triphosgene is a non-volatile alternative to phosgene and is widely used in chemical synthesis. In this paper, triphosgene was utilized as the starting material to achieve the one-pot conversion of aldehydes and ketones to nitriles and amides. The generated $\mathrm{HCl}$ plays a good catalytic role in the Beckmann rearrangement reaction.

With the increasing demand for chemicals and fuels derived from fossil resources, the prospects of developing those alternatives from the catalytic transformation of renewable biomass have sparked global concern [21-26]. Among the alternatives to biomass valorization, the production of 5-hydroxymethylfurfural (HMF) from hexoses offers a versatile platform for the synthesis of furanbased chemicals such as furyl diamide, diamidine, diimidate, and diformylfuran [27, 28]. Therefore, aromatic aldehydes and ketones [29-39] such as vanillin veratraldehyde, acetovanillone, 
acetosyringone, and syringaldehyde can be obtained by the oxidative depolymerization of lignin and lignin model compounds. To further demonstrate the utility of our protocol, the one-pot strategy was utilized for the efficacious synthesis of 2,5-dicyanofuran from biomass-derived 2,5diformylfuran. In addition, lignin-derived monoaldehyde and aromatic ketone yielded beneficial nitriles and amides. Capsaicin analogs such as nonivamide, capsaicin, and phenylcapsaicin [40] (see Figure 1), as typical capsaicinoid compounds show prominent anti-inflammatory [41] and anticancer [42] properties; these compounds have been widely applied in cancer prevention [43]. Capsaicinoids are usually prepared from vanillin by reducing vanillin oxime to obtain vanillylamine, which further reacts with acyl chlorides (Schotten-Baumann) to form the final products [44-47].<smiles>CCCCCCCCC(=O)NCc1ccc(O)c(OC)c1</smiles>

Nonivamide

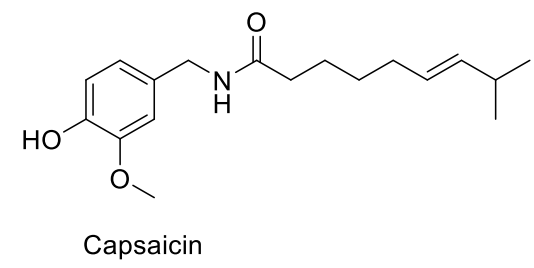

Capsaicin

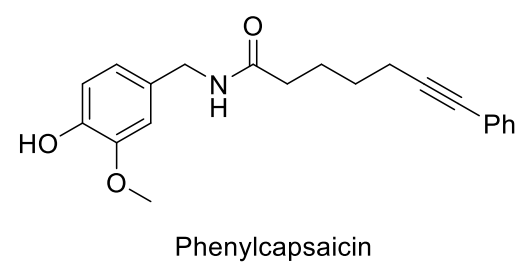

Figure 1 Examples of biologically active capsaicinoids.

Alternatively, to synthesize capsaicin analogs, our method was utilized to prepare the intermediate 4-hydroxy-3-methoxybenzonitrile (P1c-22), which can be easily used to obtain vanillylamine by hydrogenation reduction $[48,49]$. As depicted in Figure 2 , vanillylamine reacts with different fatty acid derivatives to form the amide bond and generate the corresponding capsaicinoids [50-52].

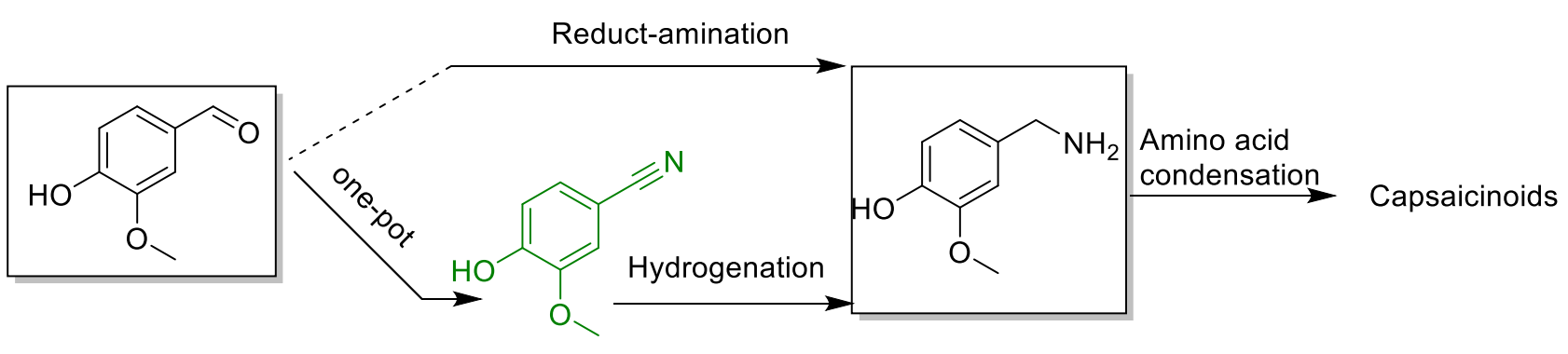

Figure 2 Methods for preparing capsaicinoids.

\section{Results and Discussion}

The reaction condition of benzaldehyde ( 1 equiv.) was initially investigated with hydroxylamine hydrochloride ( 1.5 equiv.) and triphosgene ( 0.2 equiv.) at $60{ }^{\circ} \mathrm{C}$ with acetonitrile as the solvent, yielding $97 \%$ (Table 1). In a similar method, acetanilide, the desired product of acetophenone, was obtained with a yield of $81 \%$ at $80{ }^{\circ} \mathrm{C}$ (Table 2). None of the other screened solvents were superior to acetonitrile. The reaction was investigated in the absence of triphosgene, according to benzaldehyde, and the reaction did fully convert but did not proceed much further after producing the oxime. Moreover, acetophenone has a similar pattern but lower conversion. To improve the conversion and selectivity of the aldehydes and ketones in the tandem reaction, hydroxylamine hydrochloride and triphosgene were added in steps, and the desired nitrile and acetanilide products were observed with yields of $99 \%$ and $90 \%$, respectively. (Refer to ESIt for more details) 
Table 1 Variation of standard condition for the transformation of benzaldehyde to benzonitrile.

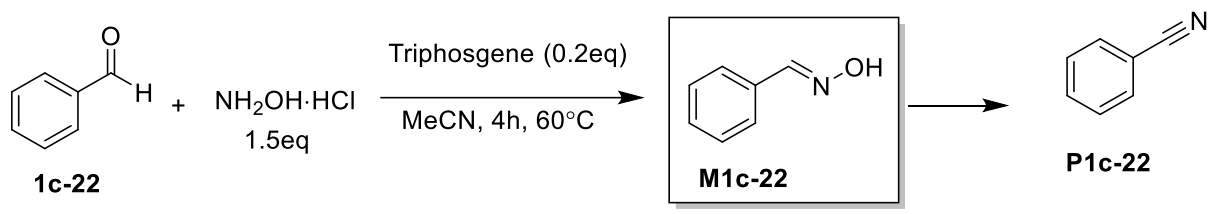

\begin{tabular}{|c|c|c|c|c|}
\hline Entry & Change from standard conditions & $\begin{array}{l}\% \\
\text { Conv. }^{a}\end{array}$ & 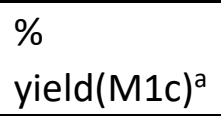 & 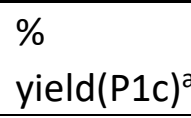 \\
\hline 1 & None & 97 & 0 & 97 \\
\hline 2 & $\mathrm{MeOH}$ instead of $\mathrm{MeCN}$ & 99 & 28 & 39 \\
\hline 3 & DCE instead of MeCN & 0 & 0 & 0 \\
\hline 4 & Toluene instead of $\mathrm{MeCN}$ & 0 & 0 & 0 \\
\hline 5 & EA instead of MeCN & 61 & 26 & 35 \\
\hline 6 & Dioxane instead of $\mathrm{MeCN}$ & 87 & 58 & 29 \\
\hline 7 & $\mathrm{rt}\left(\right.$ about $30^{\circ} \mathrm{C}$ ) instead of $60^{\circ} \mathrm{C}$ & 10 & 0 & 10 \\
\hline 9 & Without triphosgene & 95 & 48 & 47 \\
\hline 10 & After $\mathrm{NH}_{2} \mathrm{OH} \cdot \mathrm{HCl}$ for $1 \mathrm{~h}$, add triphosgene for another $3 \mathrm{~h}$. & $>99$ & 0 & $>99$ \\
\hline 11 & $10 \mu \mathrm{L} \mathrm{HCl}($ wt $37 \%$ ) instead of triphosgene & 73 & 0 & 73 \\
\hline
\end{tabular}

* Standard conditions: All reactions were performed on $0.5 \mathrm{mmol}$ scale benzaldehyde, 1.5 eq $\mathrm{NH}_{2} \mathrm{OH} \cdot \mathrm{HCl}, 0.2$ eq triphosgene at $60^{\circ} \mathrm{C}$ for $4 \mathrm{~h}$.

${ }^{a}$ Determined by GC with the GC data of $1 \mathrm{c}-22, \mathrm{M} 1 \mathrm{c}-22$, and P1c-22 as reference.

Table 2 Variation of standard conditions for the transformation of acetophenone to acetanilide.

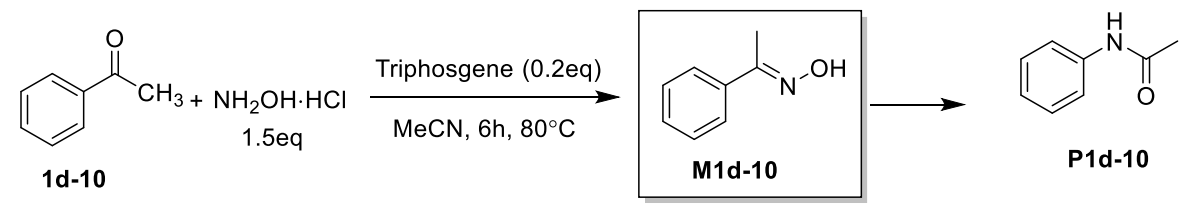

\begin{tabular}{|c|c|c|c|c|}
\hline Entry & Change from standard conditions & $\%$ Conv. $^{a}$ & $\%$ yield $(\mathrm{M} 1 \mathrm{c})^{\mathrm{a}}$ & $\%$ yield $(P 1 c)^{a}$ \\
\hline 1 & None & 92 & 7 & 81 \\
\hline 2 & $\mathrm{MeOH}$ instead of $\mathrm{MeCN}$ & 87 & 84 & 0 \\
\hline 3 & DCE instead of MeCN & 0 & 0 & 0 \\
\hline 4 & Toluene instead of MeCN & 0 & 0 & 0 \\
\hline 5 & EA instead of MeCN & 16 & 14 & 0 \\
\hline 6 & Dioxane instead of $\mathrm{MeCN}$ & 36 & 36 & 0 \\
\hline 7 & rt (about $30^{\circ} \mathrm{C}$ ) instead of $80^{\circ} \mathrm{C}$ & 0 & 0 & 0 \\
\hline 8 & Without triphosgene & 56 & 28 & 24 \\
\hline 9 & After $\mathrm{NH}_{2} \mathrm{OH} \cdot \mathrm{HCl}$ for $3 \mathrm{~h}$, add triphosgene for another $3 \mathrm{~h}$. & 96 & 4 & 91 \\
\hline 10 & $10 \mu \mathrm{L} \mathrm{HCl}$ (wt $37 \%$ ) instead of triphosgene & 68 & 28 & 35 \\
\hline
\end{tabular}

* Standard conditions: All reactions were performed on $0.5 \mathrm{mmol}$ scale acetophenone, $1.5 \mathrm{eq}$ $\mathrm{NH}_{2} \mathrm{OH} \cdot \mathrm{HCl}, 0.2$ eq triphosgene at $80^{\circ} \mathrm{C}$ for $6 \mathrm{~h}$.

${ }^{a}$ Determined by GC with the GC data of $1 d-10, M 1 d-10$, and P1d-10 as reference. 
As shown in Table 3, the reaction system for the application was assessed in aromatic and aliphatic aldehydes after the optimization of the reaction conditions. A wide array of aldehyde derivatives with various substituent groups were converted selectively, yielding corresponding nitriles in excellent yields. For instance, the tandem conversion of aliphatic aldehydes (1c-17 and 19) gave the corresponding nitrile products in $83-89 \%$ yields. Electron-withdrawing groups substituted aromatic aldehydes, such as nitro (1c-13)-and halogen (1c-3,7,14, and 15)-substituted benzaldehyde, to give the corresponding nitrile products with yields exceeding $93 \%$. On the other hand, the yields of nitriles derived from the one-pot transformation of multi-substituent benzaldehyde (1c-10) and electron-donating groups (1c-1,2,4,5,6,8,9,11,12, and 18) substituted substrates were satisfactory. The effect of steric hindrance did not affect the reactivity. For example, ortho-substituted aldehydes such as (1c-1) yielded 97\% 2-(methyl) benzonitrile (P1c-1) with the same high yield as $99 \% \mathrm{~m}$-(methyl) benzonitrile (P1c-6) and 98\% p-(methyl) benzonitrile (P1c-9). Several meta-substituted aldehydes incorporating bromo (1c-7), methoxy (1c-11), and hydroxyl (1c-4) substituents were tolerated, delivering the nitrile products in excellent yields of 93-98\%, which is comparable to the parasubstituted aldehydes. Furthermore, the good yield of nitrile product from furfural (1c-20) and its derivatives (1c-16 and 21) was observed to have a conversion rate of over $94 \%$. Based on sustainable development and green chemistry, our standard protocol was established. Accordingly, it is desirable to convert aldehydes from oxidative depolymerization of lignin into corresponding nitriles under mild conditions, such as vanillin, syringaldehyde, and veratraldehyde. As a result, corresponding nitriles were obtained with excellent conversion and selectivity. The standard protocol was examined by subjecting 2,5-diformylfuran (1c-26) to the synthesis of 2,5-dicyanofuran and obtaining the dinitrile product (P1c-26) with a conversion of above $99 \%$ and selectivity of $93 \%$. It is noteworthy that 2,5-dicyanofuran may be applied in the preparation of biomass-based commercial chemicals such as spices, medicines, and pesticides [53]. 
Table 3 Scope of aromatic, heteroaromatic, and aliphatic aldehydes a .

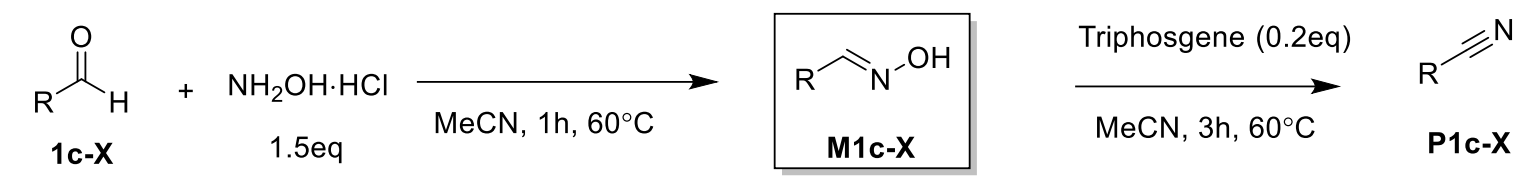<smiles>Cc1ccccc1C#N</smiles>

P1C-1<smiles>CSc1ccc(C#N)cc1</smiles>

P1c-2

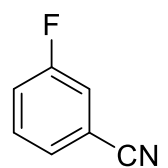

P1C-3<smiles>N#Cc1cccc(O)c1</smiles>

P1c-4

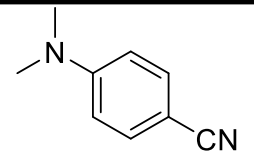

P1C-5

$>99 \%$ con. $98 \%$ sel. $\quad>99 \%$ con. $98 \%$ sel. $\quad>99 \%$ con. $96 \%$ sel. $\quad>99 \%$ con. $98 \%$ sel. $\quad>99 \%$ con. $95 \%$ sel.<smiles>Cc1cccc(C#N)c1</smiles>

P1c-6<smiles>N#Cc1cccc(Br)c1</smiles>

P1c-7<smiles>CCCOc1ccc(C#N)cc1</smiles>

P1c-8<smiles>Cc1ccc(C#N)cc1</smiles>

P1c-9

$>99 \%$ con. $99 \%$ sel. $\quad>99 \%$ con. $96 \%$ sel. $>99 \%$ con. $98 \%$ sel.

$>99 \%$ con. $98 \%$ sel.

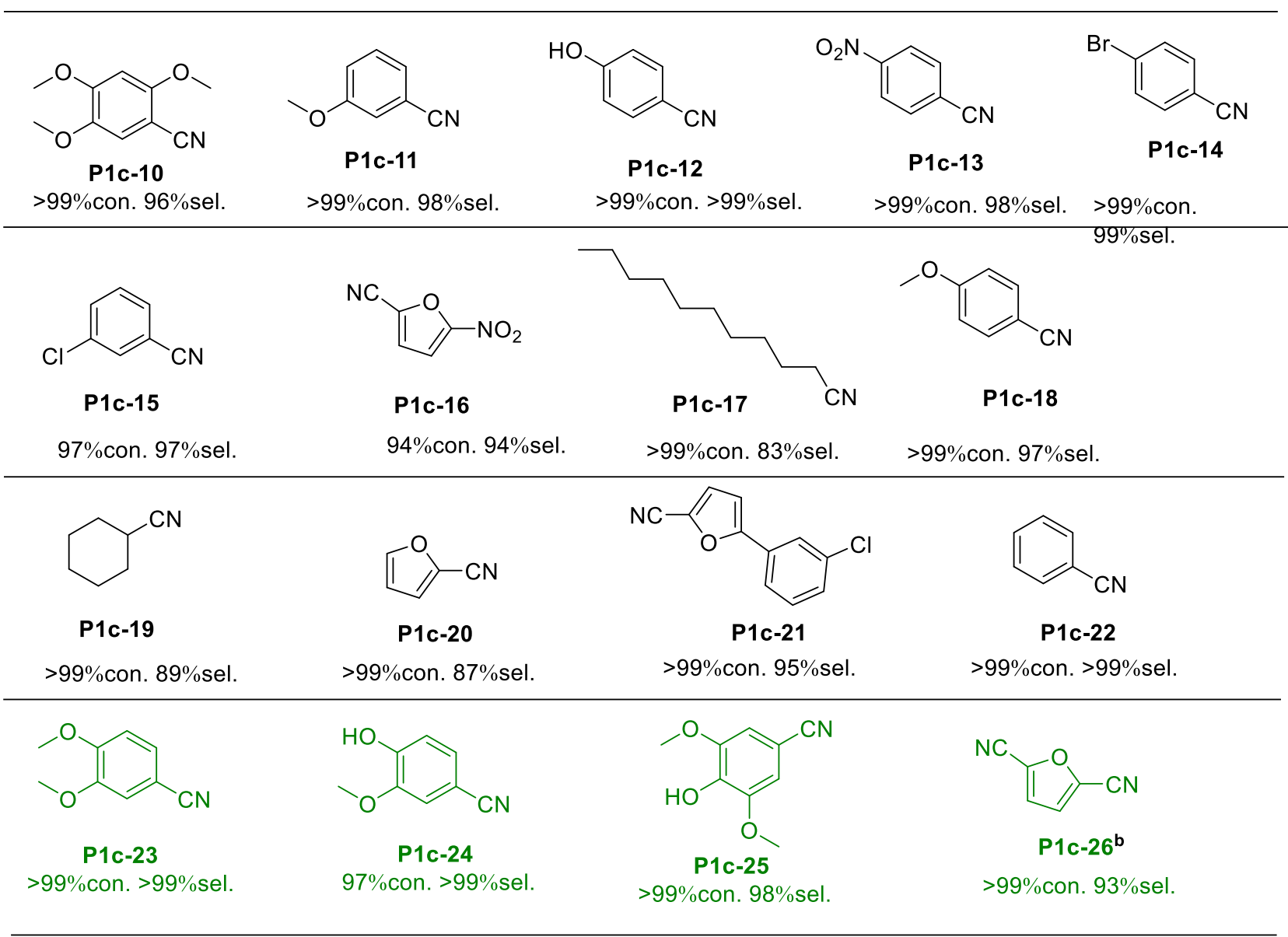

Reaction conditions: ${ }^{\mathrm{a} G e n e r a l ~ p r o c e d u r e ~ A: ~} 0.5 \mathrm{mmol}$ aldehydes, $0.75 \mathrm{mmol} \mathrm{NH} \mathrm{N}_{2} \mathrm{OH} \cdot \mathrm{HCl}, 0.1$ mmol triphosgene, $4 \mathrm{~mL} \mathrm{MeCN}, 60{ }^{\circ} \mathrm{C}, 4 \mathrm{~h}$. ${ }^{\mathrm{b}}$ General procedure C: $0.5 \mathrm{mmol}$ aldehydes, 0.75 $\mathrm{mmol} \mathrm{NH}_{2} \mathrm{OH} \cdot \mathrm{HCl}, 0.1 \mathrm{mmol}$ triphosgene, $4 \mathrm{~mL} \mathrm{MeCN}, 60^{\circ} \mathrm{C}, 4 \mathrm{~h}$. Conversion and Selectivity were determined by $\mathrm{GC} /{ }^{1} \mathrm{H}$ NMR spectroscopy.

The standard protocol followed in the preparation of amide products from various ketones (Table 4) was examined, given the relevance and broad application of amide molecules in the textile and 
pharmaceutical sectors. An array of aliphatic ketones such as (1d-2) and (1d-8) underwent our protocol smoothly, giving the corresponding amide products with yields of over $85 \%$. Phenylacetone with various substituent groups $(1 d-4,6)$ performed well. Interestingly, the yields of amide from the transformation of $p$-methyl substituted and $o(p)$-methoxy-acetophenone $(1 d-1,3$, and 7$)$ and naphthophenone were excellent. However, the yields of amides obtained from the transformation of o-methyl substituted acetophenone (1d-9) and 3,4-methylenedioxyacetophenone (2) were relatively lower but still satisfactory. As a consequence of the steric hindrance effect, the transformation of the para-methyl-substituted acetophenone (1) generated corresponding acetanilide with a higher yield (93\%) than the ortho-methyl-substituted acetophenone (9) (55\%). However, the conversion of ortho-(7) and para-methoxyl-substituted substrate (3) obtained the target products in a similarly high yield (above 90\%) due to the more important electron-induced effect. This is the underlying reason for the lower yield of the conversion of para-chlorine acetophenone (1d-5).

Table 4 Scope of aromatic, heteroaromatic, and aliphatic aldehydes ${ }^{a}$.

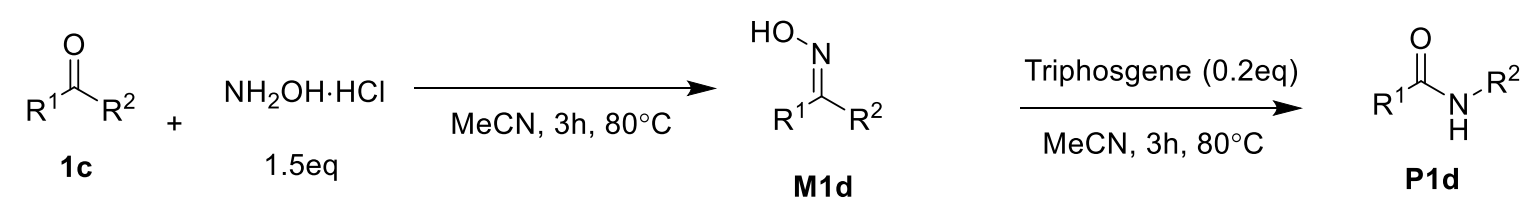<smiles>CC(=O)Nc1ccc(C)cc1</smiles>

P1d-1

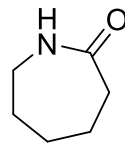

P1d-2<smiles>COc1ccc(NC(C)=O)cc1</smiles>

P1d-3

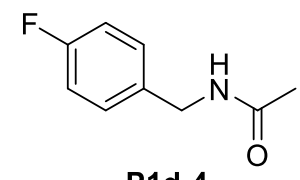

P1d-4

$97 \%$ con. $93 \%$ sel. $>99 \%$ con. $85 \%$ sel $94 \%$ con. $93 \%$ sel. $>99 \%$ con. $86 \%$ sel.

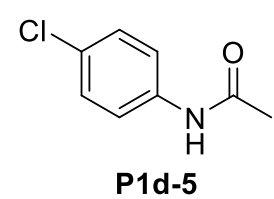

$81 \%$ con. $61 \%$ sel.

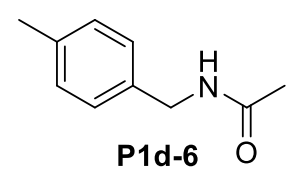

$>99 \%$ con. $81 \%$ sel.<smiles>COc1ccccc1NC(C)=O</smiles>

$>99 \%$ con. $95 \%$ sel.<smiles>CCCCCCCCNC(C)=O</smiles>

$>99 \%$ con. $96 \%$ sel.<smiles>CC(=O)Nc1ccccc1C</smiles>

P1d-9

$58 \%$ con. $94 \%$ sel.

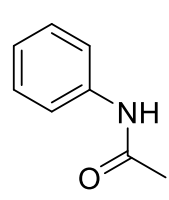

P1d-10

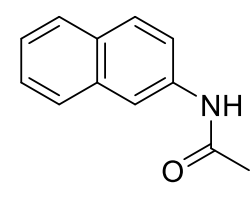

P1d-11

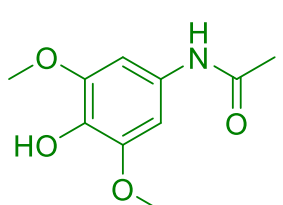

P1d-12

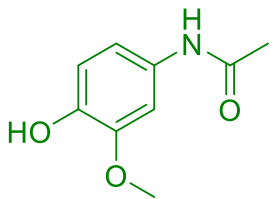

P1d-13

96\%con. 95\%sel.

$97 \%$ con. $93 \%$ sel.

$85 \%$ con. $94 \%$ sel.

$97 \%$ con. $>93 \%$ sel.

a Reaction conditions: General procedure B: $0.5 \mathrm{mmol}$ aldehydes, $0.75 \mathrm{mmol} \mathrm{NH} \mathrm{N}_{2} \mathrm{OH} \cdot \mathrm{HCl}, 0.1$ mmol triphosgene, $4 \mathrm{~mL} \mathrm{MeCN}, 80^{\circ} \mathrm{C}, 4 \mathrm{~h}$. Conversion and Selectivity were determined by GC/ ${ }^{1} \mathrm{H}$ NMR spectroscopy.

Scheme 1 illustrates a plausible route, including two steps for this nitrile one-pot. Initially, the attack of hydroxylamine hydrochloride on aldehyde gives an intermediate oxime M1c, which then undergoes triphosgene-assisted dehydration to give the desired nitrile product $\mathrm{P} 1 \mathrm{c}$. The reaction mechanism of the first step is clear in this process. To investigate the acting property of triphosgene 
for these oximes and confirm the reaction mechanism of the oxime to nitrile conversion, as described in Scheme 2, 1c-22 was selected as a representative; ${ }^{1} \mathrm{H}$ NMR titration experiments and $\mathrm{GC}$ analyses were performed. As shown in Figure $3 \mathrm{~A}$, the ${ }^{1} \mathrm{H}$ NMR spectra were recorded after adding triphosgene to a solution of benzaldehyde oxime in $\mathrm{CD}_{3} \mathrm{CN}$. The spectra showed that the hydroxyl proton $\left(H_{d}\right)$ signal at $8.9 \mathrm{ppm}$ disappeared and the formyl proton $\left(H_{c}\right)$ signal at $8.3 \mathrm{ppm}$ of benzaldehyde oxime shrank gradually after the addition of triphosgene. The aldehydic proton signals sharply appeared at $10.1 \mathrm{ppm}\left(\mathrm{H}_{\mathrm{a}}\right)$, while the proton signal of benzonitrile arose at $7.7 \mathrm{ppm}\left(\mathrm{H}_{\mathrm{b}^{\prime}}\right)$. As shown in Figure $3 \mathrm{~B}$, based on the GC analysis of that final reaction solution, the same result as ${ }^{1} \mathrm{HNMR}$, including benzaldehyde and benzonitrile, was obtained. As for acetophenone oxime, the hydroxyl proton $\left(\mathrm{H}_{\mathrm{e}}\right)$ signal at $8.85 \mathrm{ppm}$ disappeared and the $\mathrm{Ar}-\mathrm{H}(7.65 \mathrm{ppm})$ and $-\mathrm{CH}_{3}(2.25 \mathrm{ppm})$ signals were shifted $\left(\mathrm{H}_{b^{\prime \prime}}\right.$ to $\mathrm{H}_{b^{\prime}}$ and $\mathrm{H}_{\mathrm{b}} ; \mathrm{H}_{\mathrm{d}}$ to $\mathrm{H}_{\mathrm{c}}$ and $\left.\mathrm{H}_{\mathrm{e}}\right)$, indicating the conversion of oxime to amide and ketone and shown in Figure 4A. Consequently, acetanilide and acetophenone were formed, and the GC data verified this conclusion (Figure 4B).

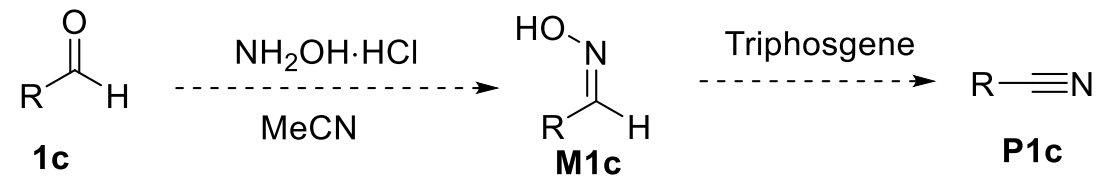

Scheme 1 The route of preparation of nitriles (P1c) from aldehydes.

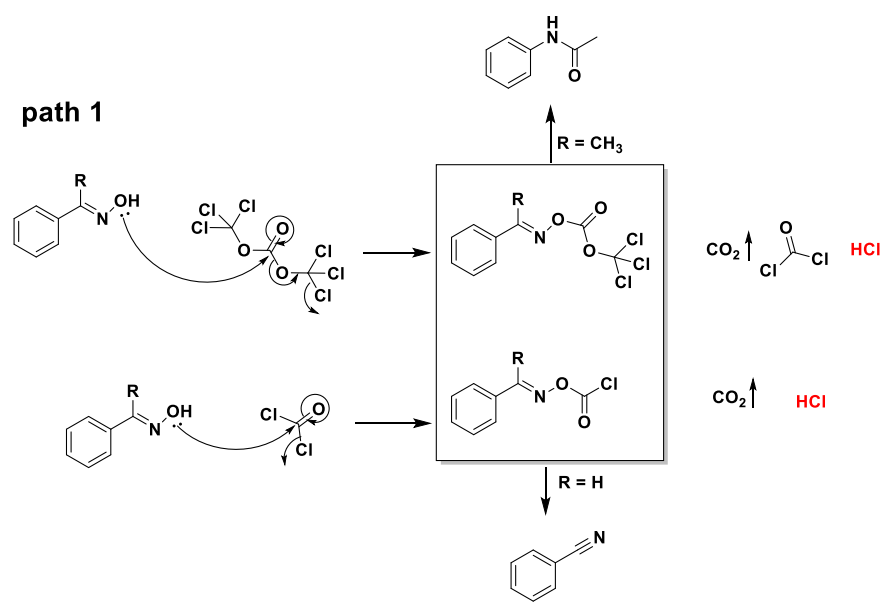

path 2

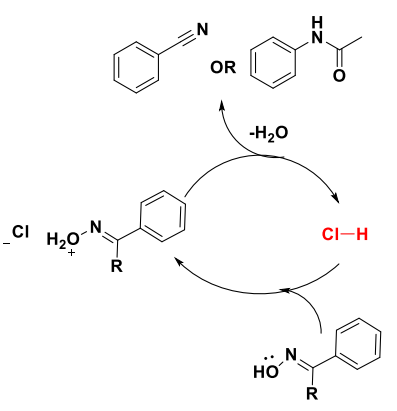

Scheme 2 Proposed reaction mechanism of oximes with triphosgene. 

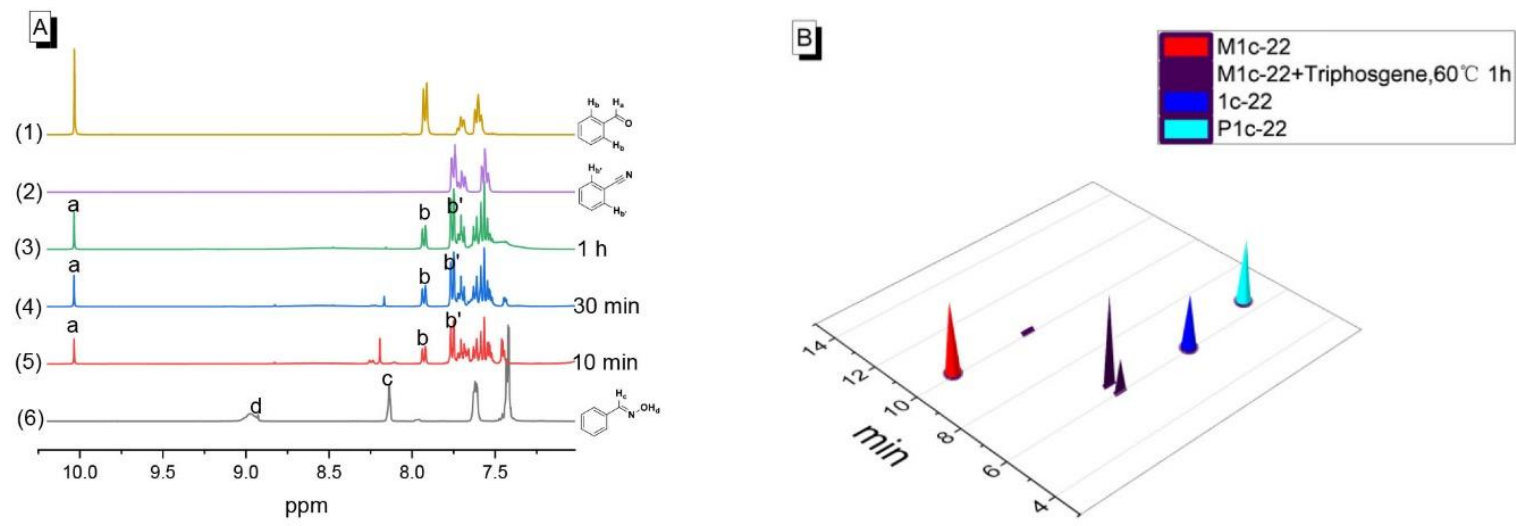

Figure 3 (A) Partial 1H NMR spectra of M1c-22 (0.5 mM) in $\mathrm{CD}_{3} \mathrm{CN}$ before (6) and after the addition triphosgene 0.1 equiv in $\mathrm{CD}_{3} \mathrm{CN}$ at $60{ }^{\circ} \mathrm{C}$ for $10 \mathrm{~min}(5), 30 \mathrm{~min}$ (4), $1 \mathrm{~h} \mathrm{(3)}$ and reference NMR spectrum of P1c-22 (2) and $1 \mathrm{c}-22$ (1) in $\mathrm{CD}_{3} \mathrm{CN}$. (B) Partial GC spectra of M1c-22 (0.5 mM) with 0.1 equiv triphosgene in $\mathrm{CH}_{3} \mathrm{CN}$ at $60{ }^{\circ} \mathrm{C}$ for $1 \mathrm{~h}$, and reference $\mathrm{GC}$ spectrum of $1 \mathrm{c}-22, \mathrm{M} 1 \mathrm{c}-22$ and $\mathrm{P} 1 \mathrm{c}-22$ in $\mathrm{CH}_{3} \mathrm{CN}$.

A]

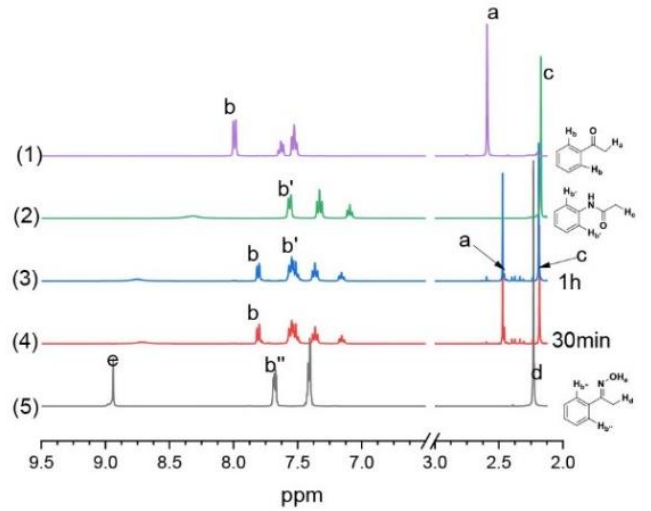

B]

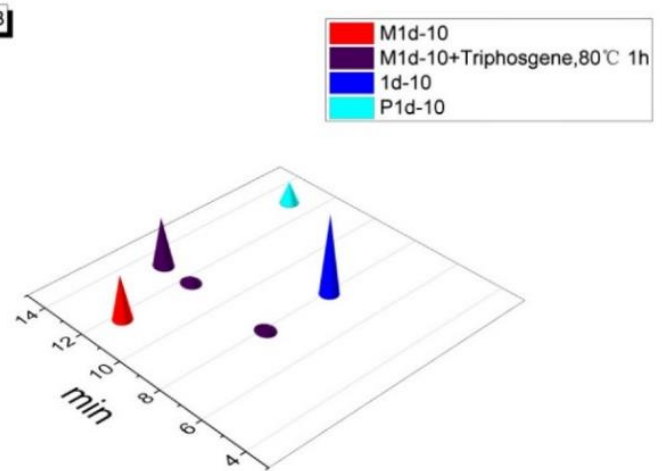

Figure 4 (A) Partial ${ }^{1} \mathrm{H}$ NMR spectra of $\mathrm{M} 1 \mathrm{~d}-10(0.5 \mathrm{mM})$ in $\mathrm{CD}_{3} \mathrm{CN}$ before (6) and after the addition triphosgene 0.1 equiv in $\mathrm{CD}_{3} \mathrm{CN}$ at $80{ }^{\circ} \mathrm{C}$ for $10 \mathrm{~min}$ (5), $30 \mathrm{~min}$ (4), $1 \mathrm{~h} \mathrm{(3)}$ and reference NMR spectrum of P1d-10 (2) and $1 d-10$ (1) in $\mathrm{CD}_{3} \mathrm{CN}$. (B) Partial GC spectra of $\mathrm{M} 1 \mathrm{~d}-10$ (0.5 mM) with 0.1 equiv triphosgene in $\mathrm{CH}_{3} \mathrm{CN}$ at $80^{\circ} \mathrm{C}$ for $1 \mathrm{~h}$, and reference GC spectrum of $1 d-10, \mathrm{M} 1 \mathrm{~d}-10$ and $\mathrm{P} 1 \mathrm{~d}-10$ in $\mathrm{CH}_{3} \mathrm{CN}$.

Therefore, the reaction mechanism of the conversion of aldoxime to nitrile or amide should be described as follows: Along path 1, the hydroxyl of oxime attacks triphosgene forming O((trichloromethoxy)carbonyl) oxime as intermediate, as well as phosgene and $\mathrm{HCl}$, which reacts nucleophilically with phosgene or $\mathrm{HCl}$ and follows the same path to form O-chlorocarbonyl oxime or amino oxonium. Soon, the deprotonation of the carbonyl oxime and amino oxonium converts to the final nitrile. Along path 2, $\mathrm{HCl}$ functioned as a catalyst to facilitate Beckman Rearrangement, which was consistent with the reported acid catalysis in general. The experiments verified the catalytic effect of $\mathrm{HCl}$ (Table 1, Entry11; Table 2, Entry10). Besides, the transformation of aldoxime into amide also undergoes Beckman Rearrangement by using triphosgene and $\mathrm{HCl}$, as shown in Scheme 2. 


\section{Conclusions}

The practical protocol was successfully applied to a wide scope of substrates with diverse functional groups, including biomass-derived aldehydes and ketones with excellent conversions and yields by utilizing the tandem reaction of aldehydes and ketones with hydroxylamine hydrochloride in the presence of triphosgene to construct nitriles and amides, respectively. Among them, the nitrile prepared from vanillin can be used as a precursor for the synthesis of capsaicin. The conversion of oximes is slightly inferior when directly reacting with triphosgene. Furthermore, a plausible mechanism was proposed that the reaction undergoes deprotonation or rearrangement, and the one-pot reaction from aldehydes as precursors was found to be more applicable than the conversion of oximes to nitriles.

\section{Acknowledgments}

This work was supported financially by the National Key R\&D Program of China (2018YFB1501500), National Natural Science Foundation of China (51976225).

\section{Author Contributions}

J. G. L. and L. L. M supervised and designed the research. X.Z.W wrote the original manuscript. J. $G$. $L$ reviewed and corrected the manuscript. All authors discussed the results and assisted during manuscript preparation.

\section{Competing Interests}

The authors declare no competing financial interests.

\section{Additional Materials}

The following additional materials are uploaded at the page of this paper.

1. Figure $\mathrm{S} 1:{ }^{1} \mathrm{H} \mathrm{NMR}\left(400 \mathrm{MHz}, \mathrm{CDCl}_{3}\right)$ after the reaction of $1 \mathrm{c}-1$.

2. Figure S2: GC (1c-1 retention time: $8.345 \mathrm{~min}$ ) after the reaction of $1 \mathrm{c}-1$.

3. Figure $\mathrm{S3}:{ }^{1} \mathrm{H} \mathrm{NMR}\left(400 \mathrm{MHz}, \mathrm{CDCl}_{3}\right)$ after the reaction of $1 \mathrm{c}-2$.

4. Figure S4: GC (1c-2 retention time: $13.926 \mathrm{~min}$ ) after the reaction of $1 \mathrm{c}-2$.

5. Figure $\mathrm{S} 5:{ }^{1} \mathrm{H} \mathrm{NMR}\left(400 \mathrm{MHz}, \mathrm{CDCl}_{3}\right)$ after the reaction of $1 \mathrm{c}-3$.

6. Figure S6: GC (1c-3 retention time: $5.833 \mathrm{~min}$ ) after the reaction of $1 \mathrm{c}-3$.

7. Figure $\mathrm{S7}:{ }^{1} \mathrm{H} \mathrm{NMR}\left(400 \mathrm{MHz}, \mathrm{CDCl}_{3}\right)$ after the reaction of $1 \mathrm{c}-4$.

8. Figure S8: GC (1c-4 retention time: $11.966 \mathrm{~min})$ after the reaction of $1 \mathrm{c}-4$.

9. Figure S9: ${ }^{1} \mathrm{H} N M R\left(400 \mathrm{MHz}, \mathrm{CDCl}_{3}\right)$ after the reaction of $1 \mathrm{c}-5$.

10. Figure S10: GC (1c-5 retention time: $15.51 \mathrm{~min})$ after the reaction of $1 \mathrm{c}-5$.

11. Figure S11: ${ }^{1} \mathrm{H} \mathrm{NMR}\left(400 \mathrm{MHz}, \mathrm{CDCl}_{3}\right)$ after the reaction of $1 \mathrm{c}-6$.

12. Figure S12: GC (1c-6 retention time: $8.2 \mathrm{~min}$ ) after the reaction of $1 \mathrm{c}-6$.

13. Figure $\mathrm{S} 13:{ }^{1} \mathrm{H} \mathrm{NMR}\left(400 \mathrm{MHz}, \mathrm{CDCl}_{3}\right)$ after the reaction of $1 \mathrm{c}-7$.

14. Figure S14: GC (1c-7 retention time: $10.894 \mathrm{~min}$ ) after the reaction of 1c-7.

15. Figure S15: ${ }^{1} \mathrm{H} N M R\left(400 \mathrm{MHz}, \mathrm{CDCl}_{3}\right)$ after the reaction of $1 \mathrm{c}-8$. 
16. Figure S16: GC (1c-8 retention time: $13.797 \mathrm{~min}$ ) after the reaction of $1 \mathrm{c}-8$. 17. Figure $\mathrm{S} 17:{ }^{1} \mathrm{H} \mathrm{NMR}\left(400 \mathrm{MHz}, \mathrm{CDCl}_{3}\right)$ after the reaction of $1 \mathrm{c}-9$.

18. Figure S18: GC (1c-9 retention time: $8.28 \mathrm{~min}$ ) after the reaction of $1 \mathrm{c}-9$. 19. Figure S19: ${ }^{1} \mathrm{H} \mathrm{NMR}\left(400 \mathrm{MHz}, \mathrm{CDCl}_{3}\right)$ after the reaction of $1 \mathrm{c}-10$.

20. Figure S20: $\mathrm{GC}$ (1c-10 retention time: $15.966 \mathrm{~min}$ ) after the reaction of $1 \mathrm{c}-10$. 21. Figure $\mathrm{S} 21:{ }^{1} \mathrm{H} \mathrm{NMR}\left(400 \mathrm{MHz}, \mathrm{CDCl}_{3}\right)$ after the reaction of $1 \mathrm{c}-11$.

22. Figure S22: GC (1c-11 retention time: $10.333 \mathrm{~min}$ ) after the reaction of $1 \mathrm{c}-11$. 23. Figure $\mathrm{S} 23:{ }^{1} \mathrm{H} \mathrm{NMR}\left(400 \mathrm{MHz}, \mathrm{CDCl}_{3}\right)$ after the reaction of $1 \mathrm{c}-12$.

24. Figure S24: $\mathrm{GC}$ (1c-12 retention time: $12.685 \mathrm{~min}$ ) after the reaction of $1 \mathrm{c}-12$. 25. Figure $\mathrm{S} 25:{ }^{1} \mathrm{H} N M R\left(400 \mathrm{MHz}, \mathrm{CDCl}_{3}\right)$ after the reaction of $1 \mathrm{c}-13$.

26. Figure S26: GC (1c-13 retention time: $12.364 \mathrm{~min}$ ) after the reaction of $1 \mathrm{c}-13$. 27. Figure S27: ${ }^{1} \mathrm{H} N M R\left(400 \mathrm{MHz}, \mathrm{CDCl}_{3}\right.$ ) after the reaction of $1 \mathrm{c}-14$.

28. Figure S28: GC (1c-14 retention time: $10.448 \mathrm{~min}$ ) after the reaction of 1c-14. 29. Figure S29: ${ }^{1} \mathrm{H} N M R\left(400 \mathrm{MHz}, \mathrm{CDCl}_{3}\right.$ ) after the reaction of $1 \mathrm{c}-15$.

30. Figure S30: GC (1c-15 retention time: $8.902 \mathrm{~min}$ ) after the reaction of $1 \mathrm{c}-15$. 31. Figure $\mathrm{S} 31:{ }^{1} \mathrm{H} \mathrm{NMR}\left(400 \mathrm{MHz}, \mathrm{CDCl}_{3}\right)$ after the reaction of $1 \mathrm{c}-16$.

32. Figure S32: GC (1c-16 retention time: $9.886 \mathrm{~min}$ ) after the reaction of $1 \mathrm{c}-16$.

33. Figure $\mathrm{S} 33:{ }^{1} \mathrm{H} N M R\left(400 \mathrm{MHz}, \mathrm{CDCl}_{3}\right)$ after the reaction of $1 \mathrm{c}-17$.

34. Figure S34: GC (1c-17 retention time: $11.721 \mathrm{~min}$ ) after the reaction of $1 \mathrm{c}-17$. 35. Figure S35: ${ }^{1} \mathrm{H} \mathrm{NMR}\left(400 \mathrm{MHz}, \mathrm{CDCl}_{3}\right)$ after the reaction of $1 \mathrm{c}-18$.

36. Figure S36: GC (1c-18 retention time: $11.208 \mathrm{~min}$ ) after the reaction of 1c-18.

37. Figure $\mathrm{S} 37:{ }^{1} \mathrm{H} \mathrm{NMR}\left(400 \mathrm{MHz}, \mathrm{CDCl}_{3}\right)$ after the reaction of $1 \mathrm{c}-19$.

38. Figure S38: GC (1c-19 retention time: $5.68 \mathrm{~min}$ ) after the reaction of 1c-19.

39. Figure S39: ${ }^{1} \mathrm{H} \mathrm{NMR}\left(400 \mathrm{MHz}, \mathrm{CDCl}_{3}\right)$ after the reaction of $1 \mathrm{c}-20$.

40. Figure S40: GC (1c-20 retention time: $4.01 \mathrm{~min}$ ) after the reaction of $1 \mathrm{c}-20$.

41. Figure $\mathrm{S} 41:{ }^{1} \mathrm{H} \mathrm{NMR}\left(400 \mathrm{MHz}, \mathrm{CDCl}_{3}\right)$ after the reaction of $1 \mathrm{c}-21$.

42. Figure S42: GC (1c-21 retention time: $18.097 \mathrm{~min}$ ) after the reaction of $1 \mathrm{c}-21$. 43. Figure S43: ${ }^{1} \mathrm{H} N M R\left(400 \mathrm{MHz}, \mathrm{CDCl}_{3}\right)$ after the reaction of $1 \mathrm{c}-22$.

44. Figure S44: GC (1c-22 retention time: $6.091 \mathrm{~min}$ ) after the reaction of 1c-22. 45. Figure S45: ${ }^{1} \mathrm{H} \mathrm{NMR}\left(400 \mathrm{MHz}, \mathrm{CDCl}_{3}\right)$ after the reaction of $1 \mathrm{c}-23$.

46. Figure S46: GC (1c-23 retention time: $14.326 \mathrm{~min}$ ) after the reaction of 1c-23. 47. Figure $\mathrm{S} 47:{ }^{1} \mathrm{H} \mathrm{NMR}\left(400 \mathrm{MHz}, \mathrm{CDCl}_{3}\right)$ after the reaction of $1 \mathrm{c}-24$.

48. Figure S48: GC (1c-24 retention time: $13.255 \mathrm{~min}$ ) after the reaction of 1c-24. 49. Figure S49: ${ }^{1} \mathrm{H} \mathrm{NMR}\left(400 \mathrm{MHz}, \mathrm{CDCl}_{3}\right)$ after the reaction of $1 \mathrm{c}-25$.

50. Figure S50: GC (1c-25 retention time: $16.678 \mathrm{~min}$ ) after the reaction of $1 \mathrm{c}-25$.

51. Figure $\mathrm{S} 51:{ }^{1} \mathrm{H} \mathrm{NMR}\left(400 \mathrm{MHz}, \mathrm{CDCl}_{3}\right)$ after the reaction of $1 \mathrm{c}-26$.

52. Figure S52: GC (1c-26 retention time: $8.104 \mathrm{~min}$ ) after the reaction of 1c-26.

53. Figure $\mathrm{S} 53:{ }^{1} \mathrm{H} \mathrm{NMR}\left(400 \mathrm{MHz}, \mathrm{CDCl}_{3}\right)$ after the reaction of $1 \mathrm{~d}-1$.

54. Figure S54: GC (1d-1 retention time: $9.918 \mathrm{~min}$ ) after the reaction of $1 \mathrm{~d}-1$.

55. Figure $\mathrm{S} 55:{ }^{1} \mathrm{H} \mathrm{NMR}\left(400 \mathrm{MHz}, \mathrm{CDCl}_{3}\right.$ ) after the reaction of $1 \mathrm{~d}-2$.

56. Figure S56: GC (1d-2 retention time: $5.098 \mathrm{~min}$ ) after the reaction of $1 \mathrm{~d}-2$.

57. Figure $\mathrm{S} 57:{ }^{1} \mathrm{H} \mathrm{NMR}\left(400 \mathrm{MHz}, \mathrm{CDCl}_{3}\right)$ after the reaction of $1 \mathrm{~d}-3$.

58. Figure S58: GC (1d-3 retention time: $12.532 \mathrm{~min}$ ) after the reaction of $1 \mathrm{~d}-3$.

59. Figure $\mathrm{S} 59:{ }^{1} \mathrm{H} \mathrm{NMR}\left(400 \mathrm{MHz}, \mathrm{CDCl}_{3}\right)$ after the reaction of $1 \mathrm{~d}-4$. 
60. Figure S60: GC (1d-4 retention time: $9.265 \mathrm{~min}$ ) after the reaction of $1 \mathrm{~d}-4$.

61. Figure $\mathrm{S} 61:{ }^{1} \mathrm{H} N M R\left(400 \mathrm{MHz}, \mathrm{CDCl}_{3}\right)$ after the reaction of $1 \mathrm{~d}-5$.

62. Figure $\mathrm{S} 62$ : GC (1d-5 retention time: $10.711 \mathrm{~min}$ ) after the reaction of $1 \mathrm{~d}-5$.

63. Figure $\mathrm{S} 63:{ }^{1} \mathrm{H} \mathrm{NMR}\left(400 \mathrm{MHz}, \mathrm{CDCl}_{3}\right.$ ) after the reaction of $1 \mathrm{~d}-6$.

64. Figure $\mathrm{S} 64$ : GC (1d-6 retention time: $10.668 \mathrm{~min}$ ) after the reaction of $1 \mathrm{~d}-6$.

65. Figure $\mathrm{S} 65:{ }^{1} \mathrm{H} \mathrm{NMR}\left(400 \mathrm{MHz}, \mathrm{CDCl}_{3}\right)$ after the reaction of $1 \mathrm{~d}-7$.

66. Figure $\mathrm{S66}$ : $\mathrm{GC}(1 \mathrm{~d}-7$ retention time: $11.608 \mathrm{~min}$ ) after the reaction of $1 \mathrm{~d}-7$.

67. Figure $\mathrm{S} 67:{ }^{1} \mathrm{H} \mathrm{NMR}\left(400 \mathrm{MHz}, \mathrm{CDCl}_{3}\right)$ after the reaction of $1 \mathrm{~d}-8$.

68. Figure S68: GC (1d-8 retention time: $8.298 \mathrm{~min}$ ) after the reaction of $1 \mathrm{~d}-8$.

69. Figure $\mathrm{S} 69:{ }^{1} \mathrm{H} \mathrm{NMR}\left(400 \mathrm{MHz}, \mathrm{CDCl}_{3}\right.$ ) after the reaction of $1 \mathrm{~d}-9$.

70. Figure S70: GC (1d-9 retention time: $9.201 \mathrm{~min}$ ) after the reaction of $1 \mathrm{~d}-9$.

71. Figure $\mathrm{S} 71:{ }^{1} \mathrm{H} N M R\left(400 \mathrm{MHz}, \mathrm{CDCl}_{3}\right.$ ) after the reaction of $1 \mathrm{~d}-10$.

72. Figure S72: GC (1d-10 retention time: $7.892 \mathrm{~min}$ ) after the reaction of $1 \mathrm{~d}-10$.

73. Figure S73: ${ }^{1} \mathrm{H} N M R\left(400 \mathrm{MHz}, \mathrm{CDCl}_{3}\right)$ after the reaction of $1 \mathrm{~d}-11$.

74. Figure S74: GC (1d-11 retention time: $16.297 \mathrm{~min}$ ) after the reaction of $1 \mathrm{~d}-11$.

75. Figure S75: ${ }^{1} \mathrm{H} \mathrm{NMR}\left(400 \mathrm{MHz}, \mathrm{CDCl}_{3}\right)$ after the reaction of $1 \mathrm{~d}-12$.

76. Figure S76: $\mathrm{GC}(1 \mathrm{~d}-12$ retention time: $17.639 \mathrm{~min})$ after the reaction of $1 \mathrm{~d}-12$.

77. Figure $\mathrm{S} 77:{ }^{1} \mathrm{H} \mathrm{NMR}\left(400 \mathrm{MHz}, \mathrm{CDCl}_{3}\right)$ after the reaction of $1 \mathrm{~d}-13$.

78. Figure S78: GC (1d-13 retention time: $14.552 \mathrm{~min}$ ) after the reaction of $1 \mathrm{~d}-13$.

\section{Reference}

1. Hyodo K, Togashi K, Oishi N, Hasegawa G, Uchida K. Brønsted acid catalyzed nitrile synthesis from aldehydes using oximes via transoximation at ambient temperature. Org Lett. 2017; 19: 3005-3008.

2. Pradal A, Evano G. A vinylic Rosenmund-von Braun reaction: Practical synthesis of acrylonitriles. ChemComm. 2014; 50: 11907-11910.

3. Friedman L, Shechter $H$. Preparation of nitriles from halides and sodium cyanide. An advantageous nucleophilic displacement in dimethyl sulfoxide ${ }^{1 a}$. J Org Chem. 1960; 25: 877-879.

4. Zhang X, Xia A, Chen H, Liu Y. General and mild nickel-catalyzed cyanation of aryl/heteroaryl chlorides with $\mathrm{Zn}(\mathrm{CN})_{2}$ : Key roles of DMAP. Org Lett. 2017; 19: 2118-2121.

5. Sundermeier M, Zapf A, Mutyala S, Baumann W, Sans J, Weiss S, et al. Progress in the palladiumcatalyzed cyanation of aryl chlorides. Chem Eur J. 2003; 9: 1828-1836.

6. Anbarasan P, Schareina T, Beller M. Recent developments and perspectives in palladiumcatalyzed cyanation of aryl halides: Synthesis of benzonitriles. Chem Soc Rev. 2011; 40: 50495067.

7. de Figueiredo RM, Suppo JS, Campagne JM. Nonclassical routes for amide bond formation. Chem Rev. 2016; 116: 12029-12122.

8. Smiley R, Arnold C. Aliphatic nitriles from alkyl chlorides. J Org Chem. 1960; 25: 257-258.

9. Chaumonnot A, Lamy F, Sabo-Etienne S, Donnadieu B, Chaudret B, Barthelat JC, et al. Catalytic isomerization of cyanoolefins involved in the adiponitrile process. $\mathrm{C}-\mathrm{CN}$ bond cleavage and structure of the nickel $\pi$-allyl cyanide complex $\mathrm{Ni}\left(\eta^{3}-1-\mathrm{Me}^{-} \mathrm{C}_{3} \mathrm{H}_{4}\right)(\mathrm{CN})(\mathrm{dppb})$. Organometallics. 2004; 23: 3363-3365.

10. Bini L, Müller C, Wilting J, von Chrzanowski L, Spek AL, Vogt D. Highly selective hydrocyanation 
of butadiene toward 3-pentenenitrile. J Am Chem Soc. 2007; 129: 12622-12623.

11. Tolman CA, McKinney RJ, Seidel WC, Druliner JD, Stevens WR. Homogeneous nickel-catalyzed olefin hydrocyanation. Adv Catal. 1985; 33: 1-46.

12. Xu Y, Jia X, Ma J, Gao J, Xia F, Li X, et al. Efficient synthesis of 2, 5-dicyanofuran from biomassderived 2, 5-diformylfuran via an oximation-dehydration strategy. ACS Sustain Chem Eng. 2018; 6: 2888-2892.

13. Mudshinge SR, Potnis $\mathrm{CS}, \mathrm{Xu} \mathrm{B}$, Hammond GB. HCl. DMPU-assisted one-pot and metal-free conversion of aldehydes to nitriles. Green Chem. 2020; 22: 4161-4164.

14. Gurjar J, Bater J, Fokin VV. Sulfuryl fluoride mediated conversion of aldehydes to nitriles. Chem Eur J. 2019; 25: 1906-1909.

15. Fang WY, Qin HL. Cascade process for direct transformation of aldehydes (RCHO) to nitriles (RCN) using inorganic reagents $\mathrm{NH}_{2} \mathrm{OH} / \mathrm{Na}_{2} \mathrm{CO}_{3} / \mathrm{SO}_{2} \mathrm{~F}_{2}$ in DMSO. J Org Chem. 2019; 84: 5803-5812.

16. Kim TI, Hwang B, Bouffard J, Kim Y. Instantaneous colorimetric and fluorogenic detection of phosgene with a meso-oxime-BODIPY. Anal Chem. 2017; 89: 12837-12842.

17. Wei XZ, Fu YL, Xue MJ, Song QH. Synthesis of oxadiazolones with hydrazides: The mechanism and the sensing application as sensitive, rapid, and visual fluorescent sensors for phosgene. Org Lett. 2019; 21: 9497-9501.

18. Cotarca L, Delogu P, Nardelli A. Bis (trichloromethyl) carbonate in organic synthesis. Synthesis. 1996; 1996: 553-576.

19. Su W, Zhong W, Bian G, Shi X, Zhang J. Recent advances in the chemistry of trichloromethyl chloroformate and bis-(trichloromethyl) carbonate. Org Prep Proced Int. 2004; 36: 499-547.

20. Steven R, David P. Chemical and biological warfare. Boston: Boston; 1969.

21. Besson M, Gallezot P, Pinel C. Conversion of biomass into chemicals over metal catalysts. Chem Rev. 2014; 114: 1827-1870.

22. Delidovich I, Hausoul PJ, Deng L, Pfützenreuter R, Rose M, Palkovits R. Alternative monomers based on lignocellulose and their use for polymer production. Chem Rev. 2016; 116: 1540-1599.

23. Upton BM, Kasko AM. Strategies for the conversion of lignin to high-value polymeric materials: Review and perspective. Chem Rev. 2016; 116: 2275-2306.

24. Pelckmans M, Renders T, Van de Vyver S, Sels BF. Bio-based amines through sustainable heterogeneous catalysis. Green Chem. 2017; 19: 5303-5331.

25. Gao X, Chen X, Zhang J, Guo W, Jin F, Yan N. Transformation of chitin and waste shrimp shells into acetic acid and pyrrole. ACS Sustain Chem Eng. 2016; 4: 3912-3920.

26. Chen X, Yang H, Hülsey MJ, Yan N. One-step synthesis of N-heterocyclic compounds from carbohydrates over tungsten-based catalysts. ACS Sustain Chem Eng. 2017; 5: 11096-11104.

27. Li X, Jia X, Ma J, Xu Y, Huang Y, Xu J. Catalytic amidation of 5-hydroxymethylfurfural to 2, 5furandicarboxamide over alkali manganese oxides. Chinese J Chem. 2017; 35: 984-990.

28. Jia X, Ma J, Wang M, Ma H, Chen C, Xu J. Catalytic conversion of 5-hydroxymethylfurfural into 2 , 5-furandiamidine dihydrochloride. Green Chem. 2016; 18: 974-978.

29. Panyadee R, Posoknistakul $P$, Jonglertjunya W, Kim-Lohsoontorn $P$, Laosiripojana N, Matsagar $B M$, et al. Sequential fractionation of palm empty fruit bunch and microwave-assisted depolymerization of lignin for producing monophenolic compounds. ACS Sustain Chem Eng. 2018; 6: 16896-16906.

30. Ouyang X, Ruan T, Qiu X. Effect of solvent on hydrothermal oxidation depolymerization of lignin for the production of monophenolic compounds. Fuel Process Technol. 2016; 144: 181-185. 
31. Dai J, Styles GN, Patti $A F$, Saito K. $\mathrm{CuSO}_{4} / \mathrm{H}_{2} \mathrm{O}_{2}$-catalyzed lignin depolymerization under the irradiation of microwaves. ACS Omega. 2018; 3: 10433-10441.

32. Kumar A, Biswas B, Bhaskar T. Effect of cobalt on titania, ceria and zirconia oxide supported catalysts on the oxidative depolymerization of prot and alkali lignin. Bioresour Technol. 2020; 299: 122589.

33. Hafezisefat P, Lindstrom JK, Brown RC, Qi L. Non-catalytic oxidative depolymerization of lignin in perfluorodecalin to produce phenolic monomers. Green Chem. 2020; 22: 6567-6578.

34. Voitl T, Rudolf von Rohr P. Oxidation of lignin using aqueous polyoxometalates in the presence of alcohols. ChemSusChem. 2008; 1: 763-769.

35. Rawat S, Gupta P, Singh B, Bhaskar T, Natte K, Narani A. Molybdenum-catalyzed oxidative depolymerization of alkali lignin: Selective production of Vanillin. Appl Catal A Gen. 2020; 598: 117567.

36. Hosoya T, Yamamoto K, Miyafuji H, Yamada T. Selective production of bio-based aromatics by aerobic oxidation of native soft wood lignin in tetrabutylammonium hydroxide. RSC Adv. 2020; 10: 19199-19210.

37. Klinger GE, Zhou Y, Foote JA, Wester AM, Cui Y, Alherech M, et al. Nucleophilic thiols reductively cleave ether linkages in lignin model polymers and lignin. ChemSusChem. 2020; 13: 4394-4399.

38. Li YX, Zhu JP, Zhang ZJ, Qu YS. Preparation of syringaldehyde from lignin by catalytic oxidation of perovskite-type oxides. ACS Omega. 2020; 5: 2107-2113.

39. Song Y, Motagamwala AH, Karlen SD, Dumesic JA, Ralph J, Mobley JK, et al. A comparative study of secondary depolymerization methods on oxidized lignins. Green Chem. 2019; 21: 3940-3947.

40. Palo-Nieto C, Afewerki S, Anderson M, Tai CW, Berglund P, Córdova A. Integrated heterogeneous metal/enzymatic multiple relay catalysis for eco-friendly and asymmetric synthesis. ACS Catal. 2016; 6: 3932-3940.

41. Sancho R, Lucena C, Macho A, Calzado MA, Blanco-Molina M, Minassi A, et al. Immunosuppressive activity of capsaicinoids: Capsiate derived from sweet peppers inhibits NF$\mathrm{KB}$ activation and is a potent antiinflammatory compound in vivo. Eur J Immunol. 2002; 32: 1753-1763.

42. Macho A, Lucena C, Sancho R, Daddario N, Minassi A, Muñoz E, et al. Non-pungent capsaicinoids from sweet pepper. Eur J Nutr. 2003; 42: 2-9.

43. Luo XJ, Peng J, Li YJ. Recent advances in the study on capsaicinoids and capsinoids. Eur J Pharmacol. 2011; 650: 1-7.

44. Nelson EK. Vanillyl-acyl amides. J Am Chem Soc. 1919; 41: 2121-2130.

45. Gannett PM, Nagel DL, Reilly PJ, Lawson T, Sharpe J, Toth B. Capsaicinoids: Their separation, synthesis, and mutagenicity. J Org Chem. 1988; 53: 1064-1071.

46. Kaga H, Miura M, Orito K. A facile procedure for synthesis of capsaicin. J Org Chem. 1989; 54 : 3477-3478.

47. Wang B, Yang F, Shan YF, Qiu WW, Tang J. Highly efficient synthesis of capsaicin analogues by condensation of vanillylamine and acyl chlorides in a biphase $\mathrm{H}_{2} \mathrm{O} / \mathrm{CHCl}_{3}$ system. Tetrahedron. 2009; 65: 5409-5412.

48. Zhang $\mathrm{Y}$, Yang $\mathrm{H}$, Chi Q, Zhang Z. Nitrogen-doped carbon-supported nickel nanoparticles: $\mathrm{A}$ robust catalyst to bridge the hydrogenation of nitriles and the reductive amination of carbonyl compounds for the synthesis of primary amines. ChemSusChem. 2019; 12: 1246-1255.

49. Liu Y, He S, Quan Z, Cai H, Zhao Y, Wang B. Mild palladium-catalysed highly efficient 
hydrogenation of $\mathrm{C}$ [triple bond, length as $\mathrm{m}$-dash] $\mathrm{N}, \mathrm{C}-\mathrm{NO}_{2}$, and $\mathrm{C}$ [double bond, length as $\mathrm{m}$ dash] $\mathrm{O}$ bonds using $\mathrm{H}_{2}$ of $1 \mathrm{~atm}$ in $\mathrm{H}_{2} \mathrm{O}$. Green Chem. 2019; 21: 830-838.

50. Kobata K, Yoshikawa K, Kohashi M, Watanabe T. Enzymatic synthesis of capsaicin analogs with liver acetone powder. Tetrahedron Lett. 1996; 37: 2789-2790.

51. Kobata K, Toyoshima M, Kawamura M, Watanabe T. Lipase-catalyzed synthesis of capsaicin analogs using natural oils as an acyl donor. Biotechnol Lett. 1998; 20: 781-783.

52. Koreishi $M$, Zhang D, Imanaka $H$, Imamura $K$, Adachi $S$, Matsuno $R$, et al. A novel acylase from Streptomyces mobaraensis that efficiently catalyzes hydrolysis/synthesis of capsaicins as well as $\mathrm{N}$-acyl-L-amino acids and N-acyl-peptides. J Agric Food Res. 2006; 54: 72-78.

53. Shook BC, Chakravarty D, Barbay JK, Wang A, Leonard K, Alford V, et al. Substituted thieno [2, 3-d] pyrimidines as adenosine $A_{2 A}$ receptor antagonists. Bioorganic Med Chem Lett. 2013; 23: 2688-2691.

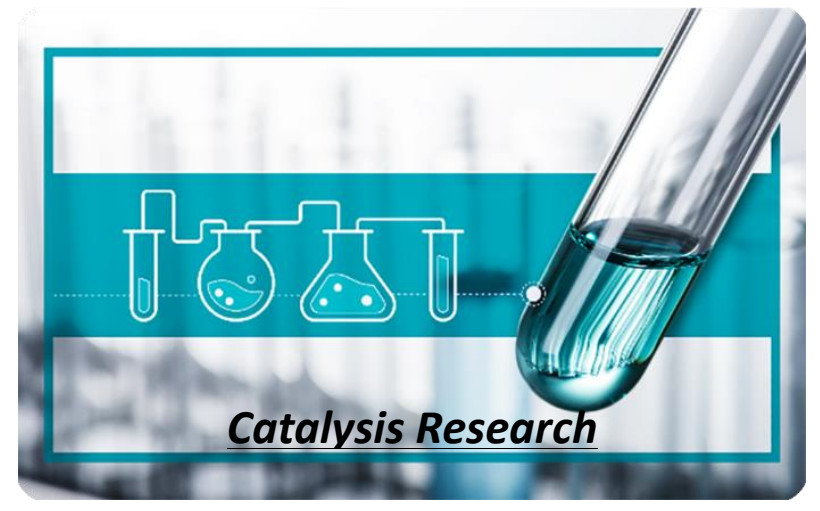

Enjoy Catalysis Research by:

1. Submitting a manuscript

2. Joining in volunteer reviewer bank

3. Joining Editorial Board

4. Guest editing a special issue

For more details, please visit: http://www.lidsen.com/journals/cr 